\title{
Modelling a Marketing-based Solution for the Paddy Marketing Crisis in Sri Lanka: Case of the Upuldeniya Warehouse Storage Receipt System
}

\author{
R.P.I.R. Prasanna \\ Department of Social Sciences, Faculty of Social Sciences and Humanities, \\ Rajarata University of Sri Lanka \\ prasannarjt@gmail.com
}

Received: 06 August 2019

Accepted: 17 October 2019

\section{ABSTRACT}

The issue of paddy marketing characterizes the paddy sector crisis, as farmers cannot realize the expected price at the harvesting period due to the bulk of supply. This paper attempts to study the effectiveness of a new marketing-based model - Warehouse Storage Receipt System (WSRS) - to solve the paddy sector crisis in Sri Lanka. Primary data for the study were drawn from field surveys conducted among farmers and traders in the Huruluwewa Agriculture Colonization Scheme in the Anuradhapura district, and in-depth interviews were conducted among the officers in the Upuldeniya WSRS in the scheme. A descriptive-analytical technique was employed in the study due to the nature of the investigated problem. The results first indicated that a majority of paddy farmers sell their harvest during the harvesting period at the lowest price, leading to inadequate net income from paddy farming. Secondly, the study revealed the oligopolistic nature of paddy marketing structure, since a few large-scale traders handle a substantial share of the farmers' production. The lower financial capability of the farmers to cover variable costs of paddy farming and pre-modern economic characteristics of the paddy marketing channel have allowed large-scale traders to grab the farmers' production at a minimum price during the harvesting period. Thirdly, WSRS evaluation has revealed that the farmers could enhance the net income of paddy farming by adequately marketing their harvest via the WSRS, as it improves the harvest holding capability of farmers until they realize a Farmer Expected Price (FEP). The 
study modelled that the WSRS leads to improve market competition through supply management, and thereby gradually increases the price at the harvesting period and shortens the price movement period to create equilibrium, which has been the farmers' expectation.

Keywords: Farmer Expected Price, Paddy marketing, Paddy production, Sri Lanka, Warehouse Storage Receipt System

\section{Introduction}

As cited in the literature, the main crisis of paddy farming in Sri Lanka is the insufficient profit derived from spending a large amount of money on farming (Prasanna \& Ranathilake, 2018). The term 'profit' $(\pi)$ is defined as the difference between total revenue $(T R)$ and the total cost (TC) of paddy farming $(\pi=T R-T C)$. The key variables affecting the total revenue of paddy farming are the price $(P)$ and quantity $(Q)$ of production. The price of paddy is mainly related to the nature of the paddy marketing structure. The quantity of production is heavily dependent upon productivity and cultivated area at an aggregated level. In a disaggregated level, the characteristics of farmers reveal that almost all farmers are smallholders and produce a small amount for the market, which is not influential in determining the selling price of farmers; thus, paddy farmers are price takers in the market. There is no considerable heterogeneity of paddy varieties produced by the farmers in terms of quality and shape, and hence, a broad price variation of different rice varieties cannot be observed in the market. It indicates the homogeneity of the farmer product - paddy. Also, literature cites numerous reasons that explain why farmers are not receiving a fair price for their produce at harvesting time. Among them, the weaknesses of government paddy purchasing mechanism, weak socioeconomic status of farmers at the harvesting time, oligopolistic nature of the rice marketing channel, and the lack of support of agriculture-related institutions were primarily documented (Damayanthi, 2006; Henegedara, 2006; Wijesooriya et al., 2017; Prasanna, 2018; Ranathilaka \& Arachchi, 2019). 
As measures to address the issue of less profitability of paddy farming, the government introduced the guaranteed price scheme (GPS) for paddy, and the Paddy Marketing Board (PMB) was established in 1971 to realize the market GPS. The GPS was mainly introduced to boost farmers' income by offering them an assured price to protect them from middlemen in the paddy marketing channel. In 1980s, as in other sectors, market-oriented policy reforms were introduced to the sector under the structural adjustment program (SAP), arguing that government operation in agricultural marketing (inputs and output markets) is not effective and efficient, and do not support to promote the interest of farmers and consumers (Prasanna \& Ranathilake, 2018). As a result, the significance of the PMB and Multi-purpose Cooperative Societies (MPCS) in paddy marketing declined due to the competition of the private traders.

For example, during the 1980s, the open market price of paddy exceeded the guaranteed price, rendering the government paddy purchasing institutions as financially unviable (Weerahewa, 2004). However, since the 1990s, the government had been unable to maintain the market GPS, particularly at the harvesting time, the period in which the farmers are compelled to sell their harvest at the prevailing price at the market due to the weakest socio-economic conditions. As revealed by Gunaruwan and Yasoda(2018), the real income of paddy farmers (except the period between 1971 and 1977) has deteriorated even though the cost of production has not increased in real terms. It indicates that the failure of GPS adjustment at the market has also affected the deteriorated economic status of paddy farmers in the country.

These facts draw scholars' attention into three questions - what are the causes for the inability to realize GPS during the harvesting time? How is the existing problem conceptualized? And how are the current conceptual options modelled to solve the problem of less profitability of paddy farming in Sri Lanka?

Paying attention to these points, Wijesooriya et al. (2017) submitted a report to the agricultural authorities, emphasizing the need of modellinga new approach to solve this long-lasting issue faced by the paddy sector in 
Sri Lanka. Thus, the purpose of this empirical study is to investigate the effectiveness of this new marketing-based model - Warehouse Storage Receipt System (WSRS) - in solving the paddy sector crisis in the country.

Here, the study focuses on the following points: 1 ) identifying the nature of the paddy sector crisis from farmers' viewpoint, 2) conceptualizing the paddy marketing problem, and 3) evaluating the effectiveness of marketingbased solution [Warehouse Storage Receipt System (WSRS)] in solving the paddy sector crisis.

\section{Literature Review}

Rice is the staple food of Sri Lanka, and paddy farming is the livelihood of approximately 1.8 million farm households (Prasanna, 2018). Hence, the paddy marketing problem acquires a wider interest from the scholars due to its negative implications on the food security of the country. However, the existing state of knowledge in the field does not provide sufficient information to address the problem sustainably because the investigations rarely outline the root causes of the paddy marketing problem and do not adequately support identifying an alternative model to solve the problem.

In a report on government intervention in paddy purchasing, Wijesooriya et al. (2017) state that during the harvesting months, farm gate price of paddy is well below the GPS, particularly in areas where there are a high supply of production, low storage facilities, fewer infrastructure facilities, less private millers, and low income. The report further reveals that the government paddy purchasing mechanism has not contributed to the realization of GPS during peak harvesting periods. The articleis entirely based on secondary data and it shares the successful experience of major paddy producing countries in Asia. The report emphasizes the need for conducting research studies to find out all stakeholders' views on intervention methods in paddy marketing, particularly the programs such as the warehouse receipt financing system.

While conducting an empirical study in Huruluwewa Colonization Scheme, Prasanna (2018) investigated the nature of the problem of poor earnings of paddy farming by studying the paddy marketing channel. The study 
attempts explicitly to provide answers to two questions - what are the root causes as to why farmers are pushed to sell their harvest at a relatively low price immediately after the harvesting? And how do the private traders exploit paddy farmers during the harvesting period by offering a relatively low price? The study confirms that paddy farmers do not derive an adequate net income from paddy farming, and the majority of farmers are pushed to sell their harvest at the harvesting period at the lowest price, which may be insufficient for them even to cover the cost of production adequately. The study further reveals the oligopolistic market structure of the paddy marketing and pre-modern economic characteristics of the paddy marketing channel. These characteristics have eventually weakened the farmers' bargaining power in marketing and forced them to accept the trading terms offered by traders. The study conceptualizes the paddy marketing problem using the empirical findings and emphasizes the need for a marketing-based sustainable solution by considering the paddy farming issues.

Damayanthi (2006) studied the paddy marketing system in the Polonnaruwa district in Sri Lanka to reveal the problems in paddy marketing. The findings are primarily based on the field survey data of 500 farm households, 38 intermediaries, and 38 rice millers in the paddy marketing channel. The study specifically noted the issues related to the government paddy purchasing mechanism such as issues related to quality checking, delay in payments, delay in marketing, issues related to packing and transportation, inefficiency and corruptions in paddy purchasing mechanism, and the distant locations of paddy purchasing centers from urban areas. Also, the findings report that $85 \%$ of sampled farmers who sell their harvest to private traders have the issues related to having a fair price at the harvesting time. These results indicate the ineffectiveness of the government-led paddy purchasing mechanism to meet the need of producers and consumers.

By analyzing the economic gains of paddy farming in Sri Lanka, Henegedara (2006) revealed the fewer competitiveness in paddy marketing as the leading cause for farmers to have an unfair price or a price below the GPS at 
the harvesting period. The findings of this study confirm that price determination is mainly handled by the private traders in the paddy marketing channel, and it is mostly below the GPS. The study further reveals the less effectiveness of farmer companies, cooperative societies, and Sathosa in the realization of GPS at the market because of less capability in handling market risks.

By analyzing the welfare impacts of liberal and protectionist policies related to the paddy sector in Sri Lanka, Weerahewa (2004) revealed that liberalization would support farmers to be more competitive in an environment of significant holdings managed by entrepreneurial farmers. Senanayake and Premarathna (2016) have studied the competitiveness and efficiency of paddy market in Sri Lanka by applying tracer survey methodology, and provide less evidence on the exploitation of paddy farmers and rice consumers by the private traders using oligopolistic market practices.

The review of existing literature in the field reveals that studies have not been well-focused on the root causes for the inability of the GPS be realized at the paddy market, particularly at the harvesting time. The research evidence is insufficient to conceptualize the marketing problem faced by paddy farmers in the field and suggests a new empirical model should solve the problem.

\section{Research Methodology}

To fulfill the research objectives, the 03 items mentioned above were examined through a descriptive analysis of data collected in the Huruluwewa Agricultural Colonization Scheme (HACS). In this connection, the field interviews were conducted among the farmers and traders in the survey area and officers in the WSRS in the Scheme area in 2018. The reason for selecting the HACS area for the study was that the pilot project of the first WSRS had been located in the HACS - Upuldeniya. The scheme has approximately 4,000 farm families who primarily grow paddy in both Yala and Maha seasons. As the scheme was established in the 1950s, and the third and fourth generation of initially settled people are now farming in 
the area, the farmers' situation in the area is believed to provide a suitable illustration of the overall marketing condition of paddy farming in Sri Lanka.

Due to the nature of phenomenon to be studied, i.e., modellinga new solution which is marketing based,for paddy sector crisis, farmers who marketed their products through the WSRS and farmers who sell their harvest directly to private traders or government purchasing systems (conventional marketing channel) were selected for the farmer survey. The survey covered 140 randomly selected farmers by administering a semistructured questionnaire method. Thirty farmers of the sample have marketed their products through the WSRS, and the rest (110) have sold their produce to private traders and government purchasing mechanisms. In-depth qualitative interviews were held among the officers of the WSRS to capture the strengths and weaknesses of the system. The cost of production data was analyzedin both groups together because both groups faced similar conditions in terms of inputs, machinery, and labor in the area. The nature of the paddy marketing structure was analyzed using the data of farmers who sold their produce directly to the conventional marketing channel. The questions were designed to elicit the data to distinguish specific features of the two marketing systems - conventional and the WSRS.

The analysis section of the paper had two parts. The first section attempts to describe the nature of the paddy sector crisis in terms of cost, income, and marketing conditions using primary data of farmers who use the conventional paddy marketing channel, and conceptualize the paddy marketing problem based on the empirical data. The second section focuses on revealing the potentiality of adopting the WSRS to address the paddysector crisis using the theoretical-based approach. Here, data of farmers who use the WSRS as a marketing source were used, and analytical results of the nature of paddy sectors crisis in the survey area identified in the first section were taken to be considered for comparison purposes. 


\section{Results and Discussion}

\subsection{Nature of paddy sector crisis - analysis of farmers in the conventional marketing system}

\section{a. Socio-economic profile of the paddy farmers}

The socio-economic status of the interviewed farmers revealed that almost all farmers are smallholders with a mean farm size of 1.8 acres. This is because initial settlers were given 1 hectear(2.47 acre) by the government at the early stage of the scheme and currently, it is used by the second or third generations of initial settlers. The mean age of farmers is 56 years with 33 years of farming experience. It implies that most farmers are in the middle age, economically active, and experienced in farming. It also denotes that farming has become less attractive to the young. All farmers use their lands for paddy cultivation.

\section{b. Cost-income analysis of paddy farming}

Table 1 presents the analysis of average cost and income of paddy farming of the farmers who sold their harvest to private traders and government paddy purchasing centers in the survey area. It shows that farmers earn a net income of Rs. 22,742 per acre, which is Rs. 13.01 per kg, by spending Rs. 45,391 . As the average farm size in the area is 1.8 acres, the total net income and total cost of the average farmer in the scheme are Rs. 40,935, and Rs. 81,703 , respectively. Thus, the net income cost ratio in the area is 0.50 . Moreover, the cost-gross income ratio in the area is 0.67 . It indicates that the cost of production and unit price of paddy are the contributory factors that determine the net income of paddy farming in the area as productivity level is close to a national average level. The average selling price of paddy in the concerned season of the study was Rs. 39 and only 47 (42.7\%) farmers could sell their products above the average price. However, the distribution of farmers' net income revealed that 37 (33.6\%) farmers did not receive the deserving positive net income. 
Table 1: Details of average cost and income of paddy farming -without using the WSRS in the survey area (per acre): 2018

\begin{tabular}{|c|c|c|c|c|c|c|}
\hline Variable & \multicolumn{2}{|l|}{ Sub-variable } & $\begin{array}{l}\text { Average } \\
\text { value }\end{array}$ & Min. & Max. & St. Dev. \\
\hline \multirow{5}{*}{ Cost } & $\begin{array}{l}\text { Labor cost (family labor + } \\
\text { hired labor) }\end{array}$ & & 16,245 & 11,843 & 46,000 & 8,373 \\
\hline & Machinery cost & & 15,463 & 0 & 40,000 & 7,722 \\
\hline & $\begin{array}{l}\text { Input cost (seed cost, } \\
\text { fertilizer cost, pesticide } \\
\text { cost, herbicide cost) }\end{array}$ & & 11,236 & 2,000 & 37,268 & 7,657 \\
\hline & Packaging cost & & 1,021 & 425 & 3,500 & 782 \\
\hline & Transportation cost & & 1,426 & 500 & 5,000 & 994 \\
\hline $\begin{array}{l}\text { Cost per } \\
\text { acre }\end{array}$ & Production cost per acre & (a) & 45,391 & 12,080 & 88,240 & 16,789 \\
\hline Production & Production per acre $(\mathrm{kg})$ & (b) & 1,747 & 938 & 3,690 & 458 \\
\hline Unit cost & Cost per kg (Rs.) & (c) & 25.98 & & & \\
\hline \multirow{2}{*}{$\begin{array}{l}\text { Gross } \\
\text { income }\end{array}$} & Price per kg of paddy (Rs.) & (d) & 39 & 23 & 55 & 8 \\
\hline & $\begin{array}{l}\text { Total gross income per acre } \\
\text { (Rs.) }\end{array}$ & $\left(b^{*} d\right)$ & 68,133 & 8,800 & 166,050 & 28,277 \\
\hline \multicolumn{2}{|c|}{$\begin{array}{l}\text { Net income per acre (Rs.) (including } \\
\text { fertilizer subsidy) }\end{array}$} & & \multicolumn{4}{|l|}{22,742} \\
\hline \multicolumn{2}{|c|}{ Net income per kg of paddy (Rs.) } & $(d-c)$ & 13.01 & & & \\
\hline
\end{tabular}

Source: Authors' calculations based on field survey data

\section{c. Nature of paddy marketing structure}

Figure 1 depicts the structure of the paddy marketing channel in the survey area. Several village-level assemblers were reported in one village. The capacity of storage facilities of interviewed assemblers at the village level varied from $11,000 \mathrm{~kg}$ to $200,000 \mathrm{~kg}$. Most of them had zero transportation costs because usually, the farmers transport their harvest from the farm to 
the assembler's place. Most assemblers had their small stores, and some had concrete compounds for drying the wet paddy.

However, the assemblers do not hold the collected paddy for a long time, and $80 \%$ of them kept 50 cents from each kilogram as their profit. They usually find the capital for buying paddy by their capital or savings, pawning jewelry or registration certificates of their vehicles, and obtaining a shortterm loan from the banks.

The main feature of the channel is the hierarchical relationship between participants in the marketing channel based on the market share (Figure 1). It shows that the paddy market in the area is dominated by a few largescale traders directly via their agents, who find the required paddy procurement finance from large-scale traders and indirectly through villagelevel assemblers. At the village level, $67 \%$ and $15 \%$ of farmer products are channeled through village-level assemblers and agents of large-scale traders, and a proportion of $80 \%$ and $100 \%$ of assembled products are then shipped to large-scale traders by the village level assemblers and agents of large-scale traders respectively. Twenty percent of assembled paddy by village level assemblers is then shipped to private rice millers in nearby cities, Galenbindunuwewa, in the survey area. The nature of these private rice millers differs from large-scale traders because they operate their business within a limited geographical area and do not have an influential power to determine the paddy price at the market as large scale traders.

The government purchasing mechanism has only purchased $7 \%$ of production in the area, from which $80 \%$ have been directed to the largescale traders, particularly at the off-season. Even though, this assembled $7 \%$ of paddy by the government purchasing mechanism is a buffer stock system, which is a system that buys and stores stocks at the paddy harvesting time to prevent price falling, release of $80 \%$ of assembled paddy to the large scale traders at the off-season results in further strengthening the paddy/rice market operation of large scale traders.

Thus, it finally indicates that $74.2 \%$ of the products sold by the farmers are handled by a few large-scale traders, particularly in the region. These 
assembled paddy by the large-scale traders are ungraded and unprocessed; thus, they undertake marketing functions-finance of paddy procurement, transportation, storage, processing, rice distribution, and price determination at the farm level. Thus, these traders obtain economies of scale in the paddy market operations over a high level of operational capital (cash) along with a comparatively large area of operation.

The interviews with village-level assemblers revealed that they had to dispatch their assembled paddy to large-scale traders because they are provided with price information with the assured forward market. They play a role as commissioned agents. According to traders' interviews, large-scale traders primarily determine the farm gate price of paddy through their market power and experience in the paddy marketing channel. Before determining the paddy price at the farm gate level, these few traders analyze the supply-side and demand-side factors as well as review and forecast possible changes of government policy over rice marketing. Thus, it is posited that there is an oligopolistic market structure for paddy in the survey area since large scale traders handle a significant proportion of farmer products and primarily determine the farm gate price of paddy.

Further, the study identified the entry barriers that new traders meet at the paddy market. Specifically, the historical profile of large scale traders in the NCP revealed that the business expansion of them is an evolutionary process of over 30 years. They have started their paddy marketing operations in the early 1980 s at a level of small scale in the region. Thus, their experience in the behavior of the price of paddy at the harvesting time, understanding farmer-related issues-particularly financial issues at the harvesting time relation with village-level paddy assemblers, and experience and understanding about government paddy marketing policyrelated issues are comparatively high. Also, a high level of operational capital (cash) and a large scale of production operations of these traders have provided an opportunity to gain economies of scale from the paddy business. These facts have limited the competitiveness of the paddy market in the area. 
Figure 1: Nature of paddy marketing channel in the survey area

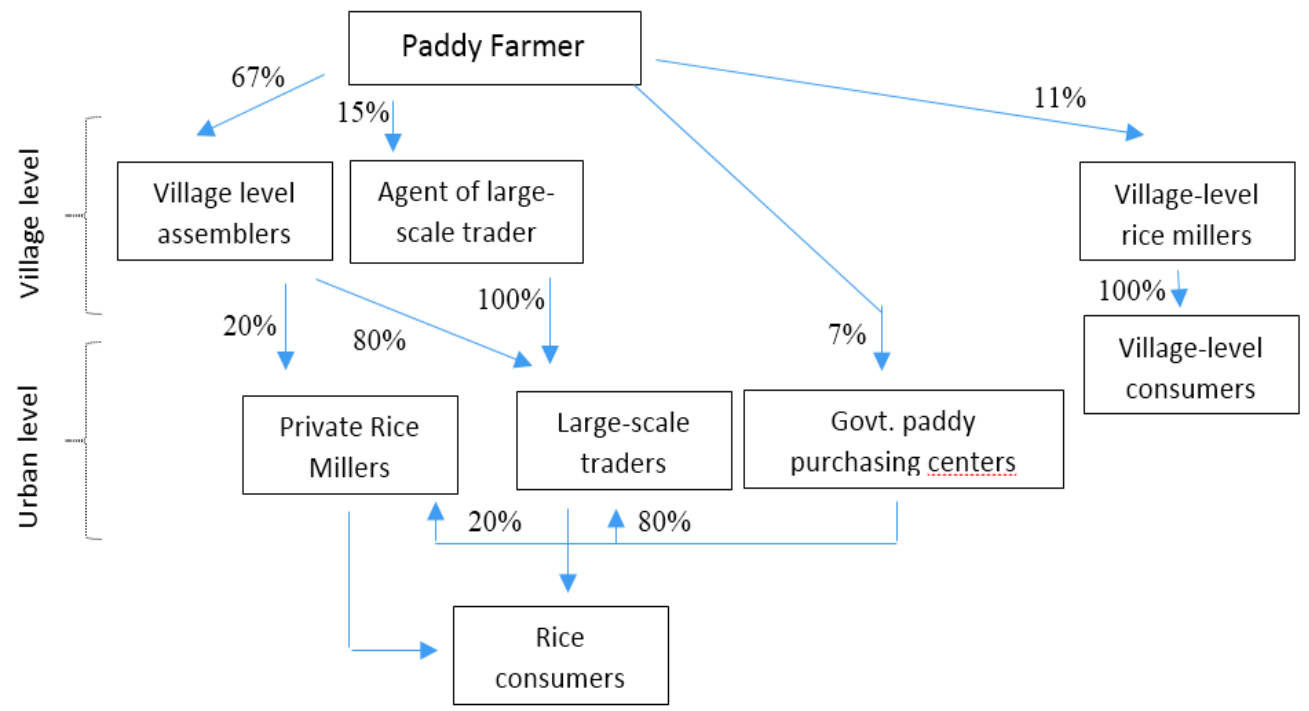

Source: Field survey, 2018

\section{d. Effects of marketing system on farmers' production and marketing}

The previous analysis revealed that large-scale traders in the paddy marketing handle all functions of marketing, including product assembling through village-level assemblers and the agents, grading, transportation, storage, processing, and price determination.

Pre-modern economic characteristics still exist in the marketing structure. For instance, assemblers use credit provisions as a strategy to maintain product supply, which in turn reduces the farmers' bargaining power. In the survey, $31.8 \%$ of farmers reported that they had to sell their paddy produce at the harvesting time, the period when paddy price is at the lowest level, to repay the loans borrowed for paddy farming (Table 2), particularly provided by the local traders. Though they are not asked to pay any interest on the received loan, they are obliged to supply the harvest at a price offered by the traders during the harvesting period. These farmers report that they have to accept the trading terms bidden by the traders due to their weakened negotiation power. The interviews with leaders of farmer 
organizations revealed that they are not undertaking paddy marketing related functions, and the main task of them is to manage water-related issues in the scheme.

Moreover, as the majority of paddy farmers are in the low-income circle due to the inadequate derivation of surplus income, they are further pressurized by the variable costs of paddy farming to sell their products at the harvesting time though prices are minimal. This was reported by $33.6 \%$ of surveyed farmers (Table 2). Most farmers use agricultural machinery for land preparation and harvesting based on paying the cost after selling the harvest. Thus, the farmers have to sell their crop within a shorter period between the harvesting time and before the onset of the next cultivation season. These factors informal credit provisions, pressure of variable cost to sell harvest at the harvesting period and financial pressure on beginning next cultivation season, and no derivation of adequate income surplus and thereby in the low-income circle have created the opportunity for private traders to exploit and dominate the paddy market, and thereby create an oligopoly market structure in the paddy sector. Thus, the revealed characteristics of the paddy market in the area indicate that farmers' marketing power is getting weaker and does not support the majority of farmers to generate surplus income from paddy farming.

Table 2: Reasons for selling output at the harvesting time

\begin{tabular}{|l|c|c|}
\hline Reason & $\begin{array}{c}\text { No. of farmers } \\
\text { (N = 110) }\end{array}$ & \% \\
\hline To repay the loan borrowed for the paddy farming & 35 & 31.8 \\
\hline $\begin{array}{l}\text { To pay wages for labor cost, input cost, and machinery } \\
\text { cost of paddy farming }\end{array}$ & 37 & 33.6 \\
\hline To repay the loan borrowed for other reasons & 9 & 8.1 \\
\hline Emergency needs & 2 & 1.8 \\
\hline Due to pest attack & 2 & 1.8 \\
\hline Insufficiency of storage facilities & 0 & 0.0 \\
\hline No specific reasons & 25 & 22.7 \\
\hline
\end{tabular}

Source: Field survey, 2018 


\subsection{Conceptualization of the nature of paddy marketing problem from}

\section{farmers' perspective, and solutions and challenges}

Figure 2 presents the nature of the paddy marketing problem from the farmers' perspective. It illustrates three demarcating price points $A=$ minimum price at the harvesting time, $B=$ average price of the surveyed sample, and $C=$ maximum price at the off-season-along with selling weeks of paddy harvest.

The results showed that 63 (57.2\%) farmers sell their harvest before eight weeks (between A and B) after harvesting (or before the next cultivation season) at a price below the average. The pressing concern of this matter is that this leads to less income in paddy farming (even a loss). There are 16 (14.5\%) farmers in the negative net income area because of selling the harvest at the harvesting period, even though their farm productivity is above the mean productivity in the area.

Figure 2 further shows a significant price difference between paddy harvesting time and off-season (17 weeks from harvest). This finding questions - why do large price differences between paddy harvesting time and off-season not encourage holding stocks by the farmers in the area? According to the study findings, the farmers' severe financial hardships at the harvesting time and dependency on informal credit sources, adopted marketing strategies by the traders at the harvesting time, and traditional or irrational behavior of farmers in selling harvest are the possible explanations for not holding stocks to gain benefits by selling harvest at the off-season. According to interviews with leaders of farmer organizations in the survey area, the farmer organizations are not in a position to undertake paddy market-related activities owing to less financial capacity and less business management experiences.

The nature of market domination by a few large scale traders in the NCP during the harvesting time can be explained by taking into account the findings of both farmers' and traders' surveys. The study identified causes that influence paddy farmers to sell their harvest in between the harvesting time and the beginning of the next cultivation season (between $A$ and $B$ ). 
Less financial capability to cover the cost of production within a cultivated season and debt trap laid by the village-level paddy assemblers are the critical factors which limit farmers' movement to higher price region (between B and C). Continuation of these issues leads to further expansion of the market power and business scale of a few large-scale traders in the region. Moreover, large scale traders undertake all marketing related functions such as finance of paddy procurement, transportation, storage, processing, rice distribution, and price determination at the farm level, and thereby obtain economies of scale in the paddy market operations.

The second hypothetical option farmers have to move to point $D$ from point $A$ at the harvesting time. It will address the issue of credit strategy laid by the traders and financial issues faced by the farmers while allowing them to move out from a low-income circle or generate surplus net income. Realization of this price can be accomplished through expansion of government paddy purchasing mechanism, extending the functions of farmer organizations or farmer cooperatives towards paddy marketing, processing and distribution, and regulating the market prices.

Figure 2: Conceptualization the nature of paddy marketing problem from the side of farmers

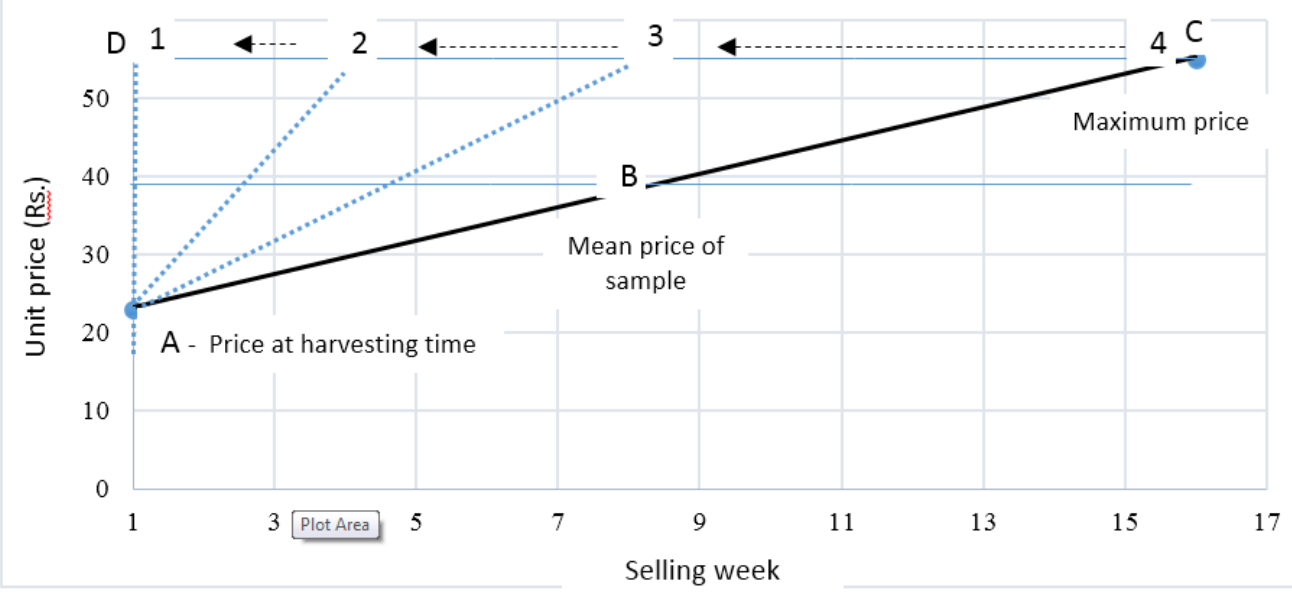

Source: Author's illustration 


\subsection{Analysis of WSRS}

Table 2 - reasons for selling output at the harvesting time - indicates that the weak financial status of the farmers at the harvesting time is the cumulative reason for the decision of selling output at the harvesting time at a relatively low price. This has allowed private traders to exploit and dominate the paddy market, thereby weakening the farmers' marketing power. Figure 1 illustrates that the government paddy purchasing mechanism through the PMB is ineffective, as it does not support to materialize GPS at harvesting time. Figure 2 provides two options to address the paddy sector crisis through a marketing-based approach; one option is to have measures to improve the holding capability of paddy harvest by farmers. The second option is to have measures to realize GPS or FEP at the harvesting time. Thus, the next section analyses the appropriateness of the WSRS as a measure to improve the holding capability of paddy harvest by the farmers and thereby solve the paddy sector crisis.

\section{a. Mechanism and Characteristics of WSRS}

In this background, the government introduced the WSRS mechanism as a pilot project in Upuldeniyain the survey area to address the marketing issues faced by the farmers. Figure 3 illustrates the mechanism and characteristics of the WSRS, which facilitates farmers to establish a relationship with the bank and traders.

(1) Shift the farmer product: Soon after harvesting, registered farmers in the WSRS could bring their harvest to the WSRS and use established facilities to dry (to reduce the wet condition of paddy from the average level of $24 \%-27 \%$ to $14 \%$ ) and use high-tech machinery to remove waste and to store.

(2) Farmers could use the receipt, which indicates the value of paddy stored at the storage time, to obtain credit facilities from the Regional Development Bank (RDB) at a low annual interest rate, which is $7 \%$. Farmers could also gain $50 \%$ of the value of paddy 
stored at the storage time, and the RDB could increase the credit amount by upto $70 \%$. Registered farmers could obtain credit during the cultivation time to cover the cost of inputs, machinery, and labor.

(3) Being a registered farmer in the WSRS, the farmers could obtain services such as low-interest credit facilities, find prospective buyers, drying and waste removing facilities, and storage facilities with modern standards.

(4) The WSRS facilitates farmers to find potential buyers, as the WSRS has registered buyers.

(5) The WSRS assures on farmer products to buyers in terms of quality.

\section{Figure 3: Mechanism and Characteristics of the WSRS}
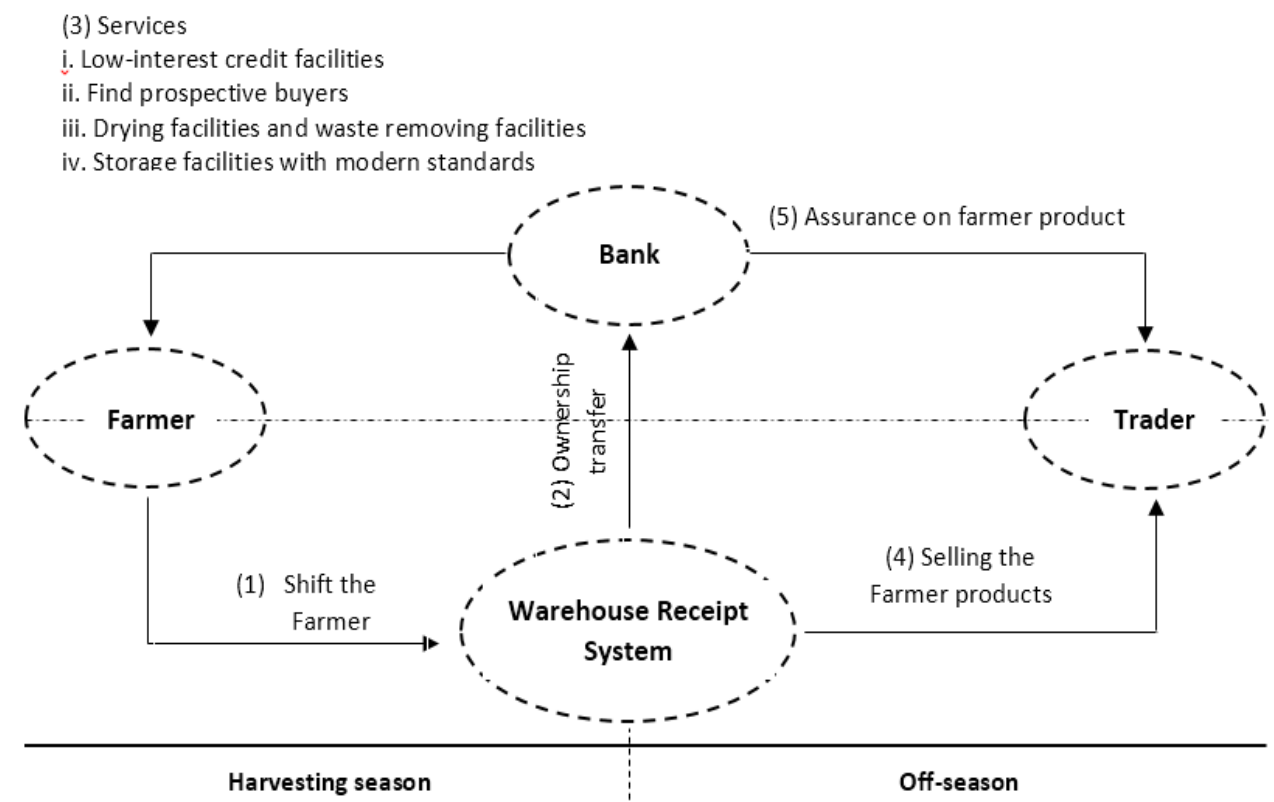

Source: Field Survey, 2018 


\section{b. Economic Effects of WSRS on the Farming Economy}

Table 3 presents the details of farmers' products marketed through the WSRS in the survey area. It denotes Rs. 16.6 per kg of price difference of paddy between the storage time and selling time. However, a difference exists between the amount of paddy at the storage time and selling time because farmers dry and remove waste before storing at the warehouse premises using the established facilities and high-tech machinery. It is estimated that this process leads to reduce $150 \mathrm{~g}$ to $200 \mathrm{~g}$ per $\mathrm{kg}$, but it improves the quality of stored paddy; hence, increasing the market value and the demand for stored paddy at the WSRS. On average, the weight difference between storage time and selling time is $780.7 \mathrm{~kg}$ for the selected sample. The farmers reported that without removing the waste or drying soon after harvesting, they could not store the paddy at their houses even for a shorter period because of rapid quality degradation. The possible explanation is the machinery (combined harvesting machine) used in harvesting.

According to farmers' estimation, they have to spend Rs. 3.75 per kg for drying and removing the waste of their products at their houses, and it is Rs. 2 per kg at the WSRS with the use of modern high-tech machinery and established other facilities. This added cost and fewer resources (labor, space, and associated equipment) for drying and removing the waste at a financially weak time also compel farmers to release their harvest to the market at a low price. Also, the farmers assume that the relatively higher weight will compensate for the price disadvantage. However, the findings of this study indicate that farmers could gain a net economic advantage of Rs. 31,673 , which is Rs. 6.04 per $\mathrm{kg}$, by storing their harvest at the WSRS.

Considering the average productivity of paddy farming in the area (i.e., which is Rs. 1,747 per acre), the farmers could increase their net income by Rs. 10,556 per acre. It is for Rs. 19,001 for average farm size of 1.8 acres in the survey area. Thus, the WSRS facilitates the average farmer in the scheme who registered in the WSRS to enhance their net income by $46.41 \%$. It means the net income of paddy farming of the average farm size (1.8 ha) in the survey area could increase from the present level of Rs. 
40,935 to Rs. 59,935. When comparing the average unit price of paddy marketed without using the WSRS, the farmers who use the WSRS could increase their net income from Rs. 13.01 to Rs. 19.72 per kg. The price difference between with and without using the WSRS is Rs. 6.71 per $\mathrm{kg}$. Moreover, the registered farmers in the WSRS are provided with the service package, including low-interest credit facilities. Further, the average farmer who does not register in the WSRS could increase their net income by $51.6 \%$ if they sold their harvest via the WSRS.

Table 3: Details of Paddy Marketed through the WSRS

\begin{tabular}{|c|c|c|c|c|c|}
\hline \multirow{2}{*}{\multicolumn{2}{|c|}{ Variable }} & \multicolumn{4}{|c|}{$\mathbf{N}=\mathbf{3 0}$} \\
\hline & & \multirow{2}{*}{$\begin{array}{c}\text { Mean } \\
5,241.6\end{array}$} & \multirow{2}{*}{$\begin{array}{c}\begin{array}{c}\text { Std. } \\
\text { Dev. }\end{array} \\
2,373.9\end{array}$} & \multirow{2}{*}{$\begin{array}{c}\text { Min. } \\
2,469\end{array}$} & \multirow{2}{*}{$\begin{array}{c}\text { Max. } \\
13,194\end{array}$} \\
\hline \multirow{3}{*}{$\begin{array}{l}\text { Details at storage } \\
\text { period }\end{array}$} & Storage amount $(\mathrm{kg})^{1}$ & & & & \\
\hline & Unit price (Rs.) $)^{2}$ & 29.1 & 3.4 & 26 & 40 \\
\hline & Total value (Rs.) & 155,417 & 88,925 & 65,317 & 525,984 \\
\hline \multirow{3}{*}{$\begin{array}{l}\text { Details at selling } \\
\text { period }\end{array}$} & Storage amount $(\mathrm{kg})$ & $4,460.9$ & $2,020.3$ & 2,101 & 11,229 \\
\hline & Unit price (Rs.) & 45.7 & 4.6 & 35 & 55 \\
\hline & Total value (Rs.) & 206,951 & 108,429 & 79,838 & 617,595 \\
\hline \multirow{2}{*}{ Value difference } & Unit value (Rs.) & 16.6 & 3.6 & 9 & 25 \\
\hline & Total value (Rs.) & 51,534 & 26,997 & 14,521 & 108,558 \\
\hline \multicolumn{2}{|c|}{ Storage period (No. of days) } & 142.1 & 50.9 & 52 & 240 \\
\hline \multicolumn{2}{|c|}{ Eligible credit amount (Rs.) ${ }^{3}$} & 77,708 & 44,462 & 32,658 & 262,992 \\
\hline \multirow{6}{*}{$\begin{array}{l}\text { Cost of storage } \\
\text { and interest } \\
\text { payment }\end{array}$} & Storage cost (Rs.) $)^{4}$ & $3,130.4$ & 1,617 & 568 & 8,312 \\
\hline & Bag (Rs.) $)^{5}$ & $2,096.5$ & 949.7 & 987 & 5,278 \\
\hline & Drying (Rs.) ${ }^{6}$ & 10,483 & 4,748 & 4,937 & 26,388 \\
\hline & Transport (Rs.) & $2,096.5$ & 949.7 & 987 & 5,278 \\
\hline & Interest (Rs.) & $2,054.5$ & $1,110.3$ & 331 & 5,613 \\
\hline & Total cost (Rs.) & 19,861 & $8,760.7$ & 8,091 & 44,937 \\
\hline \multicolumn{2}{|l|}{ Net gain (Rs.) } & 31,673 & 20,694 & 3,932 & 78,929 \\
\hline \multicolumn{2}{|c|}{ Net gain per kg (Rs.) } & 6.04 & 3.010 & 0.517 & 13.23 \\
\hline
\end{tabular}

Source: Author calculations based on the Field Survey Data 
Note: 1 . The storage amount indicates the amount that farmers bring to the WSRS or the amount before drying and removing the waste; 2 . The prevailing market price is concerned; $3.50 \%$ of the total value of storage amount at the storage period; 4 . Rs. 0.15 per kg per month of storage (30 days); 5 . Rs. 2 per bag; 6 . Considered the labor cost of both hired and family labor.

The analysis of credit provision facilitated by the WSRS shows that the average farmer in the sample could have the opportunity to obtain a loan of Rs. 80,243 from the formal financial institute - RDB - keeping the issued receipt on storage value as a guarantee with a total interest payment of Rs. 2,123 for 145 days of average storage time of paddy. This is not a burden to farmers as the WSRS facilitates the average farmer to earn Rs. 211,815 at the selling time. Thus, all financial needs related to production and consumption can be fulfilled from this credit provision by improving harvest holding capability of farmers until they receive the expected farmer price (FEP).

Moreover, the net income of Rs. 31,673 could be recognized as the previously exploited income by the participants in the paddy marketing channel in the area or the exploited amount primarily by the middlemen in the marketing channel. As the WSRS can store 10,000 MT, the optimum utilization of the warehouse leads to redistribute approximately Rs. 604 million (Rs. $6.04 * 10,000 \mathrm{MT}$ ) among smallholder paddy farmers per season, which previously outflowed from the farming economy due to exploitation by the traders. Thus, optimum utilization of the WSRS leads to redistribution of the income from trading class to farming class, thereby stimulating the stagnated farming economy.

The theoretical viewpoint of the long-run adjustment of supply and price movements is modelled under the following assumptions; price influential share of the harvest would be stored at the WSRS, the WSRS should address the weakened financial situation of the farmers, paddy production (supply) in the country is constant, and no import of rice. If the government implement this scheme in the entire country to manage farmers' harvest through the WSRSs, it is possible to assume that farmers could realize the FEP which covers the cost of production and living cost in the long-run. The 
WSRS helps to reduce the bulk release of farmers' produce to the market at the harvesting time and address the financial issues faced mainly by the farmers through credit provisions. Thus, the reduction of supply at the harvesting time gradually pressure the market to upgrade paddy prices to an FEP (Figure 4a). The continuation of this process progressively forces the market to upgrade the price at the harvesting time and shorten the price movement period to the equilibrium position along with increasing FEP (Figure 4b). Thus, as conceptualized in Figure 2, the WSRS supports to achieve the first hypothetical option - point $A$ to $C$ - in short terms, and supports market forces to achieve second hypothetical option - point $A$ to $D$ - in mid- and long-term.

Figure 4: Long-run Adjustment - Theoretical Point of View

Figure 4a:

Figure 4b:

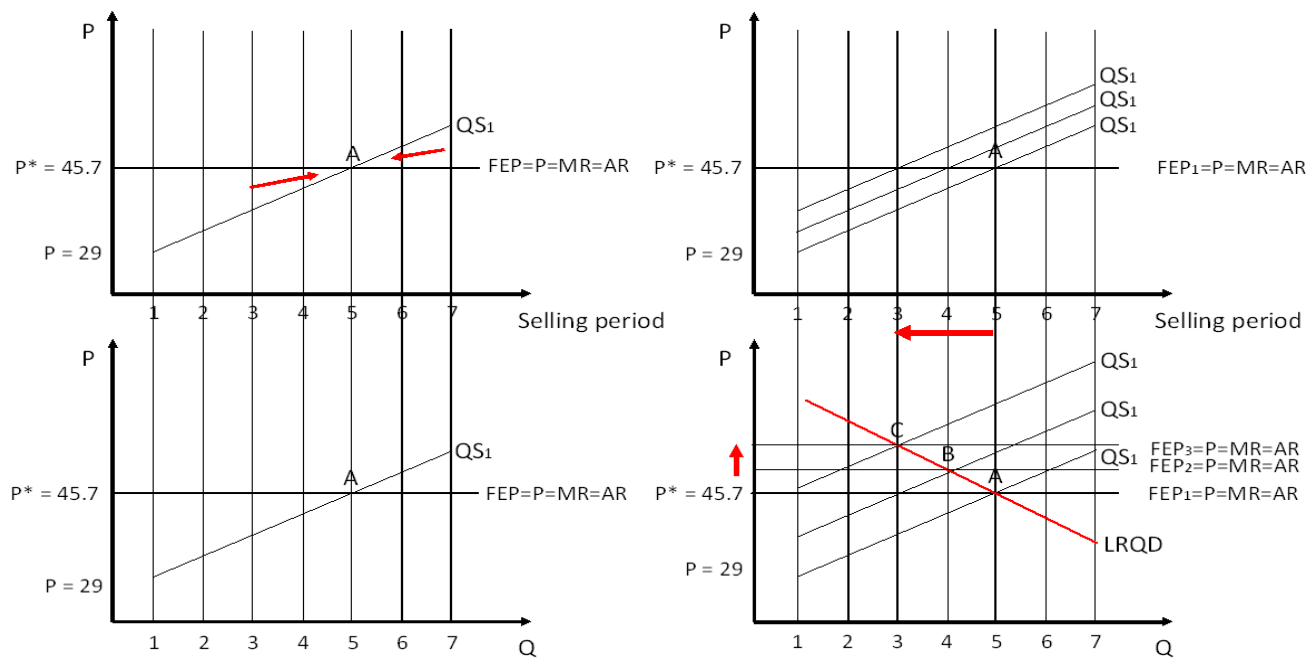

Source: Author's illustration

\section{Conclusion}

The primary aim of this study was to identify a new marketing-based solution to solve the paddy sector crisis, mainly characterized by low earnings. In this connection, three research questions were answered what are the causes why the GPS cannot be realized at the harvesting time? How is the existing problem conceptualized? And how are the existing 
conceptual options modelled to solve the problem of less profitability of paddy farming in Sri Lanka?

The results of the analysis indicated that paddy farmers do not derive adequate net income from paddy farming, and a majority of farmers sell their harvest in the harvesting period at the lowest price; this does not support them to cover the cost of production adequately. Analysis of the conventional paddy marketing channel revealed the oligopolistic nature of paddy marketing structure, as a few numbers of mass-scale traders handle a substantial proportion of farmers' production. The lower financial capability of the farmers to cover variable costs of paddy farming and premodern economic characteristics of paddy marketing channel have created the place for large-scale traders to grab the farmers' production at a minimum price during the harvesting period. Farmers do not receive any service from these traders regarding price information, inputs supply, credit provisions, or assured market for them at a reasonable price. The study also found the entry barriers that new traders face in paddy/rice marketing in the region. These barriers are the large-scale traders' extensive experience in the behavior of paddy/rice marketing channel, particularly at the harvest period, well understanding about the farmer issues-specifically the financial needs around the harvesting period-, long-term connection with village-level paddy assemblers, experience and understanding about the paddy/rice marketing policy, specifically during harvesting and off-seasons, and relatively high level of operational capital (cash) and large-scale production operations. It indicates the ineffectiveness of market-related policy reforms in enhancing efficiency in the paddy/rice marketing channel. As revealed by the analysis, one of the reasons for selling the harvest at the harvesting time is financial needs.

The evaluation of the effects of the WSRS has indicated that the WSRS could answer the fundamental question of how a farmer could sell their harvest at a farmer's expected price. It revealed that the farmer could enhance the net income of paddy farming by adequately marketing its products via the WSRS. The credit provisions at a low-interest rate have led to improving the produce holding capability of farmers until they receive the expected price. 
The study recognized the new gains received by farmers, marketing their products via the WSRS, as the amount previously exploited by the traders in the conventional marketing channel and outflowed from the farming economy. Thus, the redistribution of exploited and outflowed income to the farming class would contribute to stimulating the stagnated farming economy.

Finally, the effective implementation of the WSRS in the whole country to manage the supply of farmers produces during the harvesting period could support farmers to realize the farmer expected price. The improved competition through the supply management leads market forces (demand and supply) to pressurize the gradual increase in the price at the harvesting period and shorter price movement period to the equilibrium position, which the farmers expect over time. Based on these empirical results, the WSRS could be a suitable method to solve the paddy sector crisis primarily characterized by low income. Thus, the government should take measures to carry out large-scale investments to implement this project in the major paddy producing areas of the country.

\section{References}

Damayanthi, M., 2006. A Review of Rice Marketing Problem in Sri Lanka: Experience from Polonnaruwa District. The Journal of Agrarian Studies , pp. 53-85.

Gunaruwan, T. \& Yasoda, V., 2018. Farmers abondoning paddy cultivation: economic dimensions warranting an alternative policy perspective. Belihuloya, Sabaragamuwa University of Sri Lanka.

Henegedara, G., 2006. An Analysis of Economic Gains of Paddy Farming in Sri Lanka. Sri Lanka Journal of Agrarian Studies , pp. 1-25.

Prasanna, R., 2018. Does the Nature of Paddy Market Structure Matter for Poor Earnings of Paddy Farming? A Case of Huruluwewa Colonization Scheme in Sri Lanka. Rajarata University Journal, 5(1). 
Prasanna, R. \& Ranathilake, M., 2018. Earnings and Marketing Structure of Paddy Farming: A Case in Huruluwewa Colonization Scheme in Anuradhapura District. Peredeniya, University of Peradeniya.

Ranathilaka, M. \& Arachchi, I., 2019. The effect of fertilizer subsidy on small-scale paddy production in Sri Lanka: A case in Hinguraggoda DS division in Polonnaruwa District. Sri Lanka Journal of Economic Research, 6(2).

Senanayake, S. \& Premarathna, S., 2016. An Analysis of Paddy/Rice Value Chain in Sri Lanka, Colombo: University of Colombo.

Weerahewa, J., 2004. Impact of Trade Liberalization and Market Reforms on the Paddy/Rice Sector in Sri Lanka, Washinton DC: International Food Policy Research Institute.

Wijesooriya, N., Champika, J., Priyadharshana, D. \& Vidanapathirana, R., 2017. Government Intervention in Paddy Marketing: Issues in Purchasing and Post-stock Management, Colombo: Hector Kobbekaduwa Agrarian Research and Training Institute. 


\section{Appendix 1: Economic gains of WSRS}

\begin{tabular}{|c|c|c|c|c|c|c|c|c|c|c|c|c|c|c|c|c|c|}
\hline \multirow{2}{*}{$\begin{array}{l}\text { Far } \\
\text { mer }\end{array}$} & \multicolumn{3}{|c|}{ Details at storage period } & \multicolumn{3}{|c|}{ Details at selling period } & \multicolumn{2}{|c|}{$\begin{array}{c}\text { Value } \\
\text { difference }\end{array}$} & \multirow{2}{*}{$\begin{array}{c}\text { Storage } \\
\text { period } \\
\text { (No. of } \\
\text { days) }\end{array}$} & \multirow{2}{*}{$\begin{array}{c}\text { Eligible } \\
\text { credit } \\
\text { amount }\end{array}$} & \multicolumn{6}{|c|}{ Cost of storage and interest payment } & \multirow[t]{2}{*}{$\begin{array}{l}\text { Net } \\
\text { gain }\end{array}$} \\
\hline & $\begin{array}{c}\text { Storage } \\
\text { amount } \\
(\mathrm{kg})\end{array}$ & $\begin{array}{l}\text { Unit } \\
\text { price } \\
\text { (Rs.)* }\end{array}$ & $\begin{array}{c}\text { Total } \\
\text { value } \\
\text { (Rs.) } \\
\end{array}$ & $\begin{array}{c}\text { Storage } \\
\text { amount } \\
(\mathrm{kg})\end{array}$ & $\begin{array}{c}\text { Unit } \\
\text { price } \\
\text { (Rs.) } \\
\end{array}$ & $\begin{array}{c}\text { Total } \\
\text { value } \\
\text { (Rs.) } \\
\end{array}$ & $\begin{array}{c}\text { Unit } \\
\text { value }\end{array}$ & $\begin{array}{l}\text { Total } \\
\text { value }\end{array}$ & & & $\begin{array}{l}\text { Storage } \\
\text { cost }\end{array}$ & Bag & Drying & Transport & Interest* & $\begin{array}{l}\text { Total } \\
\text { cost }\end{array}$ & \\
\hline$(1)$ & 8,139 & 30 & 243,915 & 6,927 & 48 & $\begin{array}{r}332,49 \\
6\end{array}$ & 18 & $\begin{array}{r}88,58 \\
1\end{array}$ & 240 & 121,957 & 8,312 & 3,256 & 16,278 & 3,256 & 5,613 & 36,716 & 51,866 \\
\hline$(2)$ & 13,194 & 40 & 525,984 & 11,229 & 55 & $\begin{array}{r}617,59 \\
5\end{array}$ & 15 & $\begin{array}{r}91,61 \\
1\end{array}$ & 75 & 262,992 & 4,211 & 5,278 & 26,388 & 5,278 & 3,783 & 44,937 & 46,674 \\
\hline (3) & 2,814 & 30 & 84,560 & 2,395 & 48 & $\begin{array}{r}114,93 \\
6\end{array}$ & 18 & $\begin{array}{r}30,37 \\
6\end{array}$ & 225 & 42,280 & 2,694 & 1,125 & 5,627 & 1,125 & 1,824 & 12,396 & 17,980 \\
\hline (4) & 5,875 & 28 & 165,000 & 5,000 & 47 & $\begin{array}{r}235,00 \\
0 \\
\end{array}$ & 19 & $\begin{array}{r}70,00 \\
0\end{array}$ & 225 & 82,500 & 5,625 & 2,350 & 11,750 & 2,350 & 3,560 & 25,635 & 44,365 \\
\hline (5) & 4,152 & 40 & 165,504 & 3,534 & 55 & $\begin{array}{r}194,37 \\
0 \\
\end{array}$ & 15 & $\begin{array}{r}28,86 \\
6 \\
\end{array}$ & 70 & 82,752 & 1,237 & 1,661 & 8,305 & 1,661 & 1,111 & 13,975 & 14,892 \\
\hline (6) & 6,169 & 30 & 183,785 & 5,250 & 48 & $\begin{array}{r}252,00 \\
0 \\
\end{array}$ & 18 & $\begin{array}{r}68,21 \\
5 \\
\end{array}$ & 160 & 91,893 & 4,200 & 2,468 & 12,338 & 2,468 & 2,820 & 24,292 & 43,923 \\
\hline (7) & 2,469 & 26 & 65,317 & 2,101 & 38 & 79,838 & 12 & $\begin{array}{r}14,52 \\
1 \\
\end{array}$ & 94 & 32,658 & 987 & 987 & 4,937 & 987 & 589 & 8,489 & 6,033 \\
\hline (8) & 7,593 & 26 & 196,021 & 6,462 & 35 & $\begin{array}{r}226,17 \\
0 \\
\end{array}$ & 9 & $\begin{array}{r}30,15 \\
0 \\
\end{array}$ & 97 & 98,010 & 3,134 & 3,037 & 15,186 & 3,037 & 1,823 & 26,217 & 3,932 \\
\hline (9) & 3,740 & 27 & 101,472 & 3,183 & 41 & $\begin{array}{r}130,50 \\
3 \\
\end{array}$ & 14 & $\begin{array}{r}29,03 \\
1 \\
\end{array}$ & 183 & 50,736 & 2,912 & 1,496 & 7,480 & 1,496 & 1,781 & 15,165 & 13,866 \\
\hline (10) & 4,161 & 26 & 108,544 & 3,541 & 43 & $\begin{array}{r}152,26 \\
3 \\
\end{array}$ & 17 & $\begin{array}{r}43,71 \\
9 \\
\end{array}$ & 213 & 54,272 & 3,771 & 1,664 & 8,321 & 1,664 & 2,217 & 17,638 & 26,081 \\
\hline (11) & 5,515 & 27 & 151,616 & 4,694 & 41 & $\begin{array}{r}192,45 \\
4 \\
\end{array}$ & 14 & $\begin{array}{r}40,83 \\
8 \\
\end{array}$ & 190 & 75,808 & 4,459 & 2,206 & 11,031 & 2,206 & 2,762 & 22,665 & 18,173 \\
\hline (12) & 2,569 & 26 & 66,361 & 2,186 & 38 & 83,068 & 12 & $\begin{array}{r}16,70 \\
8\end{array}$ & 52 & 33,180 & 568 & 1,027 & 5,137 & 1,027 & 331 & 8,091 & 8,616 \\
\hline (13) & 6,011 & 26 & 153,300 & 5,116 & 43 & $\begin{array}{r}219,98 \\
8 \\
\end{array}$ & 17 & $\begin{array}{r}66,68 \\
8 \\
\end{array}$ & 124 & 76,650 & 3,172 & 2,405 & 12,023 & 2,405 & 1,823 & 21,826 & 44,862 \\
\hline (14) & 2,516 & 30 & 75,250 & 2,141 & 47 & $\begin{array}{r}100,62 \\
7 \\
\end{array}$ & 17 & $\begin{array}{r}25,37 \\
7 \\
\end{array}$ & 186 & 37,625 & 1,991 & 1,006 & 5,031 & 1,006 & 1,342 & 10,377 & 15,000 \\
\hline (15) & 2,583 & 30 & 78,365 & 2,198 & 48 & $\begin{array}{r}105,50 \\
4 \\
\end{array}$ & 18 & $\begin{array}{r}27,13 \\
9 \\
\end{array}$ & 184 & 39,182 & 2,022 & 1,033 & 5,165 & 1,033 & 1,383 & 10,636 & 16,503 \\
\hline (16) & 4,056 & 29 & 116,926 & 3,452 & 45 & $\begin{array}{r}155,34 \\
0 \\
\end{array}$ & 16 & $\begin{array}{r}38,41 \\
4 \\
\end{array}$ & 79 & 58,463 & 1,364 & 1,622 & 8,112 & 1,622 & 886 & 13,606 & 24,807 \\
\hline (17) & 10,353 & 30 & 314,370 & 8,811 & 48 & $\begin{array}{r}422,92 \\
8\end{array}$ & 18 & $\begin{array}{r}108,5 \\
58 \\
\end{array}$ & 122 & 157,185 & 5,375 & 4,141 & 20,706 & 4,141 & 3,678 & 38,041 & 70,517 \\
\hline
\end{tabular}

Peradeniya Management Review - Vol. I, Issue.02, (December) 2019 


\begin{tabular}{|c|c|c|c|c|c|c|c|c|c|c|c|c|c|c|c|c|c|}
\hline (18) & 5,396 & 27 & 143,282 & 4,592 & 48 & $\begin{array}{r}220,41 \\
6\end{array}$ & 21 & $\begin{array}{r}77,13 \\
4\end{array}$ & 154 & 71,641 & 3,536 & 2,158 & 10,791 & 2,158 & 2,116 & 20,759 & 56,375 \\
\hline (19) & 3,469 & 30 & 103,740 & 2,952 & 45 & $\begin{array}{r}132,84 \\
0 \\
\end{array}$ & 15 & $\begin{array}{r}29,10 \\
0 \\
\end{array}$ & 86 & 51,870 & 1,269 & 1,387 & 6,937 & 1,387 & 855 & 11,837 & 17,263 \\
\hline$(20)$ & 6,055 & 27 & 166,400 & 5,153 & 52 & $\begin{array}{r}267,95 \\
6 \\
\end{array}$ & 25 & $\begin{array}{r}101,5 \\
56 \\
\end{array}$ & 136 & 83,200 & 3,504 & 2,422 & 12,110 & 2,422 & 2,170 & 22,627 & 78,929 \\
\hline$(21)$ & 4,063 & 30 & 121,895 & 3,458 & 46 & $\begin{array}{r}159,06 \\
8 \\
\end{array}$ & 16 & $\begin{array}{r}37,17 \\
4 \\
\end{array}$ & 160 & 60,947 & 2,766 & 1,625 & 8,126 & 1,625 & 1,870 & 16,013 & 21,160 \\
\hline$(22)$ & 5,995 & 29 & 173,851 & 5,102 & 42 & $\begin{array}{r}214,28 \\
4\end{array}$ & 13 & $\begin{array}{r}40,43 \\
3\end{array}$ & 80 & 86,925 & 2,041 & 2,398 & 11,990 & 2,398 & 1,334 & 20,160 & 20,273 \\
\hline$(23)$ & 5,312 & 26 & 138,117 & 4,521 & 47 & $\begin{array}{r}212,48 \\
7 \\
\end{array}$ & 21 & $\begin{array}{r}74,37 \\
0 \\
\end{array}$ & 145 & 69,058 & 3,278 & 2,125 & 10,624 & 2,125 & 1,920 & 20,072 & 54,298 \\
\hline (24) & 4,559 & 29 & 132,211 & 3,880 & 45 & $\begin{array}{r}174,60 \\
0 \\
\end{array}$ & 16 & $\begin{array}{r}42,38 \\
9 \\
\end{array}$ & 155 & 66,106 & 3,007 & 1,824 & 9,118 & 1,824 & 1,965 & 17,737 & 24,652 \\
\hline (25) & 4,724 & 27 & 127,535 & 4,020 & 52 & $\begin{array}{r}209,04 \\
0 \\
\end{array}$ & 25 & $\begin{array}{r}81,50 \\
6 \\
\end{array}$ & 178 & 63,767 & 3,578 & 1,889 & 9,447 & 1,889 & 2,177 & 18,980 & 62,525 \\
\hline (26) & 3,009 & 30 & 90,275 & 2,561 & 42 & $\begin{array}{r}107,56 \\
2 \\
\end{array}$ & 12 & $\begin{array}{r}17,28 \\
7 \\
\end{array}$ & 90 & 45,138 & 1,152 & 1,204 & 6,018 & 1,204 & 779 & 10,357 & 6,930 \\
\hline (27) & 7,168 & 30 & 215,025 & 6,100 & 48 & $\begin{array}{r}292,80 \\
0 \\
\end{array}$ & 18 & $\begin{array}{r}77,77 \\
5 \\
\end{array}$ & 152 & 107,513 & 4,636 & 2,867 & 14,335 & 2,867 & 3,134 & 27,839 & 49,936 \\
\hline (28) & 4,243 & 29 & 123,045 & 3,611 & 44 & $\begin{array}{r}158,88 \\
4 \\
\end{array}$ & 15 & $\begin{array}{r}35,83 \\
9 \\
\end{array}$ & 128 & 61,522 & 2,311 & 1,697 & 8,486 & 1,697 & 1,510 & 15,701 & 20,138 \\
\hline (29) & 5,236 & 27 & 141,367 & 4,456 & 47 & $\begin{array}{r}209,43 \\
2 \\
\end{array}$ & 20 & $\begin{array}{r}68,06 \\
5 \\
\end{array}$ & 136 & 70,683 & 3,030 & 2,094 & 10,472 & 2,094 & 1,844 & 19,534 & 48,532 \\
\hline (30) & 6,112 & 31 & 189,483 & 5,202 & 45 & $\begin{array}{r}234,09 \\
0 \\
\end{array}$ & 14 & $\begin{array}{r}44,60 \\
7 \\
\end{array}$ & 145 & 94,741 & 3,771 & 2,445 & 12,225 & 2,445 & 2,635 & 23,521 & 21,087 \\
\hline Mean & $5,241.7$ & 29.1 & 155,417 & $4,460.9$ & 45.7 & 206,951 & 16.6 & $51,534.2$ & 142.1 & $77,708.5$ & $3,130.4$ & $2,096.6$ & 10,483 & $2,096.6$ & $2,054.5$ & 19,861 & 31,672 \\
\hline
\end{tabular}

Source: Field survey, 2018 